\title{
Telocytes and putative stem cells in the lungs: electron microscopy, electron tomography and laser scanning microscopy
}

\author{
Laurentiu M. Popescu • Mihaela Gherghiceanu • \\ Laura C. Suciu • Catalin G. Manole • Mihail E. Hinescu
}

Received: 26 May 2011 /Accepted: 21 July 2011 / Published online: 20 August 2011

(C) The Author(s) 2011. This article is published with open access at Springerlink.com

\begin{abstract}
This study describes a novel type of interstitial (stromal) cell - telocytes (TCs) - in the human and mouse respiratory tree (terminal and respiratory bronchioles, as well as alveolar ducts). TCs have recently been described in pleura, epicardium, myocardium, endocardium, intestine, uterus, pancreas, mammary gland, etc. (see www.telocytes. com). TCs are cells with specific prolongations called telopodes $(\mathrm{Tp})$, frequently two to three per cell. Tp are very long prolongations (tens up to hundreds of $\mu \mathrm{m}$ ) built of alternating thin segments known as podomers $(\leq 200 \mathrm{~nm}$, below the resolving power of light microscope) and dilated segments called podoms, which accommodate mitochondria, rough endoplasmic reticulum and caveolae. $\mathrm{Tp}$ ramify dichotomously, making a 3-dimensional network with complex homo- and heterocellular junctions. Confocal microscopy reveals that TCs are c-kit- and CD34-positive. $\mathrm{Tp}$ release shed vesicles or exosomes, sending macromolecular signals to neighboring cells and eventually modifying their transcriptional activity. At bronchoalveolar junctions, TCs have been observed in close association with putative stem cells ( $\mathrm{SCs}$ ) in the subepithelial stroma. SCs are recognized by their ultrastructure and Sca-1 positivity. Tp
\end{abstract}

Electronic supplementary material The online version of this article (doi:10.1007/s00441-011-1229-z) contains supplementary material, which is available to authorized users.

L. M. Popescu $(\bowtie) \cdot$ L. C. Suciu · C. G. Manole · M. E. Hinescu Department of Cellular and Molecular Medicine,

Carol Davila University of Medicine and Pharmacy,

Bucharest, Romania

e-mail: 1popescu@jcmm.org

L. M. Popescu • M. Gherghiceanu • L. C. Suciu • C. G. Manole •

M. E. Hinescu

Victor Babeș National Institute of Pathology,

Bucharest, Romania surround SCs, forming complex TC-SC niches (TC-SCNs). Electron tomography allows the identification of bridging nanostructures, which connect $\mathrm{Tp}$ with SCs. In conclusion, this study shows the presence of TCs in lungs and identifies a TC-SC tandem in subepithelial niches of the bronchiolar tree. In TC-SCNs, the synergy of TCs and SCs may be based on nanocontacts and shed vesicles.

Keywords Telocytes $\cdot$ Lung $\cdot$ Bronchioles $\cdot$ Stem cell niche $\cdot$ Cellular communication

\section{Introduction}

Lung ultrastructure was described in detail approximately 20 years ago (see Schraufnagel 1990) and there are currently standards and recommendations for the quantitative assessment of the lung structure (Matthay et al. 2010). Moreover, a joint task force of experts in lung morphology has been created to guide the research policy of the American Thoracic Society and the European Respiratory Society (Hsia et al. 2010).

Recently, we documented a new type of interstitial (stromal) cell named the telocyte (TC) (Popescu and Faussone-Pellegrini 2010; Popescu 2011a, b). The shortest possible definition of TC is: cells with telopodes (Tp). The name "telopodes" was chosen to highlight that these prolongations are extremely long (from several tens to hundreds of $\mu \mathrm{m})$ and very thin $(50-100 \mathrm{~nm})$, with a caliber usually below the resolving power of light microscope. We have described TCs in pleura (Hinescu et al. 2011) and in various organs (e.g., heart: Popescu et al. 2009, 2010, 2011a; Gherghiceanu and Popescu 2009, 2010, 2011; Gherghiceanu et al. 2010; Mandache et al. 2010; Suciu et al. 2009, 2010a; placenta: Suciu et al. 2010b; pancreas: Nicolescu et al. 2010; 
skeletal muscle: Popescu et al. 2011b). The TC concept was adopted by other laboratories (Faussone-Pellegrini and Bani 2010; Bani et al. 2010; Bojin et al. 2011; Cozzi et al. 2011; Gittenberger-de Groot et al. 2010; Klumpp et al. 2010; Kostin 2010; Polykandriotis et al. 2010; Susman et al. 2010; Zhou et al. 2010; Tommila 2010; Eyden et al. 2011; Cantarero et al. 2011a, b; Gard and Asirvatham 2011; Gevaert et al. 2011; Kostin 2011; Li et al. 2010; Limana et al. 2011; Radenkovic 2011; Rupp et al. 2010; Russell et al. 2011; Rusu et al 2011a, b; Xiao et al. 2011).

The aim of this study was to establish whether TCs are present in human and rodent lungs, particularly in bronchiolar tree stroma. We observed TCs using 2-dimensional (2D) transmission electron microscopy and 3-dimensional (3D) electron tomography, as well as laser scanning microscopy. In addition, as in epicardial SCNs (Popescu 2011a, b; Popescu et al. 2009, 2010, 2011a, b; Gherghiceanu and Popescu 2010) or in skeletal muscle (Popescu et al. 2011b), we found a close association of TCs with putative stem cells (SCs) within the bronchiolar SCNs. Different groups of stem cells, at the level of bronchoalveolar junctions, have been described previously (Kim et al. 2005; Kim 2007; Kotton and Fine 2008; Liu and Engelhardt 2008; Warburton et al. 2008; Jiang and Li 2009; Chistiakov 2010). Sca-1 was used to establish cell lineage relationships of lung stem/progenitor cells to differentiated progeny (Raiser and Kim 2009).

\section{Materials and methods}

Small rodent lung samples were obtained from four 8-monthold C57BL/6 mice. Human lung samples were obtained from two patients undergoing surgery for neoplastic lung diseases. The Bioethics Committee of the "Victor Babeș" National Institute of Pathology, Bucharest, approved this study in accordance with generally accepted international standards.

\section{Transmission electron microscopy}

Transmission electron microscopy (TEM) was performed on small $\left(1 \mathrm{~mm}^{3}\right)$ lung tissue samples, which were processed according to a routine Epon-embedding procedure that we have previously described (Popescu et al. 2009). Thin sections $(60 \mathrm{~nm})$ were double-stained with uranyl acetate and lead citrate and examined with a Morgagni 286 transmission electron microscope (FEI Company, Eindhoven, The Netherlands) at $60 \mathrm{kV}$. Digital electron micrographs were recorded with a MegaView III CCD using iTEM-SIS software (Olympus, Soft Imaging System GmbH, Münster, Germany). TEM images were digitally colored using Adobe (C) Photoshop CS3 to highlight TC (colored in blue).
Electron microscope tomography

Electron microscope tomography (ET) was performed on 250-nm-thick sections of Epon-embedded tissue using a Tecnai G2 Spirit BioTwin transmission electron microscope with a single-tilt specimen holder (FEI Company) at $100 \mathrm{kV}$. Electron tomographic data sets were recorded with a MegaView G2 CCD camera (Olympus) in ET mode. Projection images $(1024 \times 1024$ pixels $)$ were acquired at 1-degree angular increments from $-65^{\circ}$ to $+65^{\circ}$ about an axis perpendicular to the optical axis of the microscope, at $36,000 \times$ magnification (pixel size $2.65 \mathrm{~nm}$ ). After data alignment, the data sets were reconstructed into 3D volume (data collection, reconstruction and visualization) using Xplore3D Tomography Suite software (FEI Company). Amira 5.0.1 software (Visage Imaging $\mathrm{GmbH}$, Berlin, Germany) was used for 3D imaging.

\section{Immunofluorescence on frozen sections}

Frozen sections $(60 \mu \mathrm{m}$ thick) were fixed in $4 \%$ formaldehyde for $30 \mathrm{~min}$, washed for $30 \mathrm{~min}$ in PBS $(\mathrm{pH} 7.4)$ and blocked with $2 \%$ BSA. The samples were then incubated overnight at $4{ }^{\circ} \mathrm{C}$ in PBS with $0.1 \%$ (vol/ vol) Triton X-100 and 2\% normal goat or donkey serum (all from Sigma Chemical, St. Louis, MO, USA) with rabbit anti-c-kit antibody, rat anti-CD34 antibody, or both, for double immunostaining labeling (both antibodies from Santa Cruz Biotechnology, Santa Cruz, CA, USA). After washing in PBS with $0.1 \%$ (vol/vol) Triton $\mathrm{X}-100$, sections were incubated with AlexaFluorconjugated secondary goat anti-rabbit or donkey anti-rat antibodies (Invitrogen Molecular Probes, Eugene, OR, USA) for another $2 \mathrm{~h}$ at room temperature. Following an extensive washing step, the nuclei were stained with $1 \mu \mathrm{g} / \mathrm{ml} \mathrm{4}$,6-diamidino-2-phenylindole (DAPI) (Sigma Chemical, St. Louis, MO, USA). Negative controls were obtained by omitting the primary antibody, in an otherwise similar protocol.

Three to five immunolabeled sections from each case were examined by laser scanning microscopy, with a Nikon A1 laser on an ECLIPSE Ti-E inverted microscope.The confocal images were collected using a Plan Fluor $60 \times$ Oil objective, 1.25 -NA water ( $z$-axis step $0.16 \mu \mathrm{m}$ ).

The following lasers and emission filters were used to visualize the labeled structures and collect images: Ar laser at $488 \mathrm{~nm}$ (used for the excitation of Alexa Fluor 488), emission filter $500-550 \mathrm{~nm}, 561.2 \mathrm{~nm}$ G-HeNe laser (for Alexa Fluor 546), emission filter 570-620 nm and $405 \mathrm{~nm}$ Laser diode and $425-475 \mathrm{~nm}$ emission filter (for DAPI).

To improve image quality, some of the original laser scanning microscopy data were subjected to digital deconvolution with the Bitplane Imaris module. 

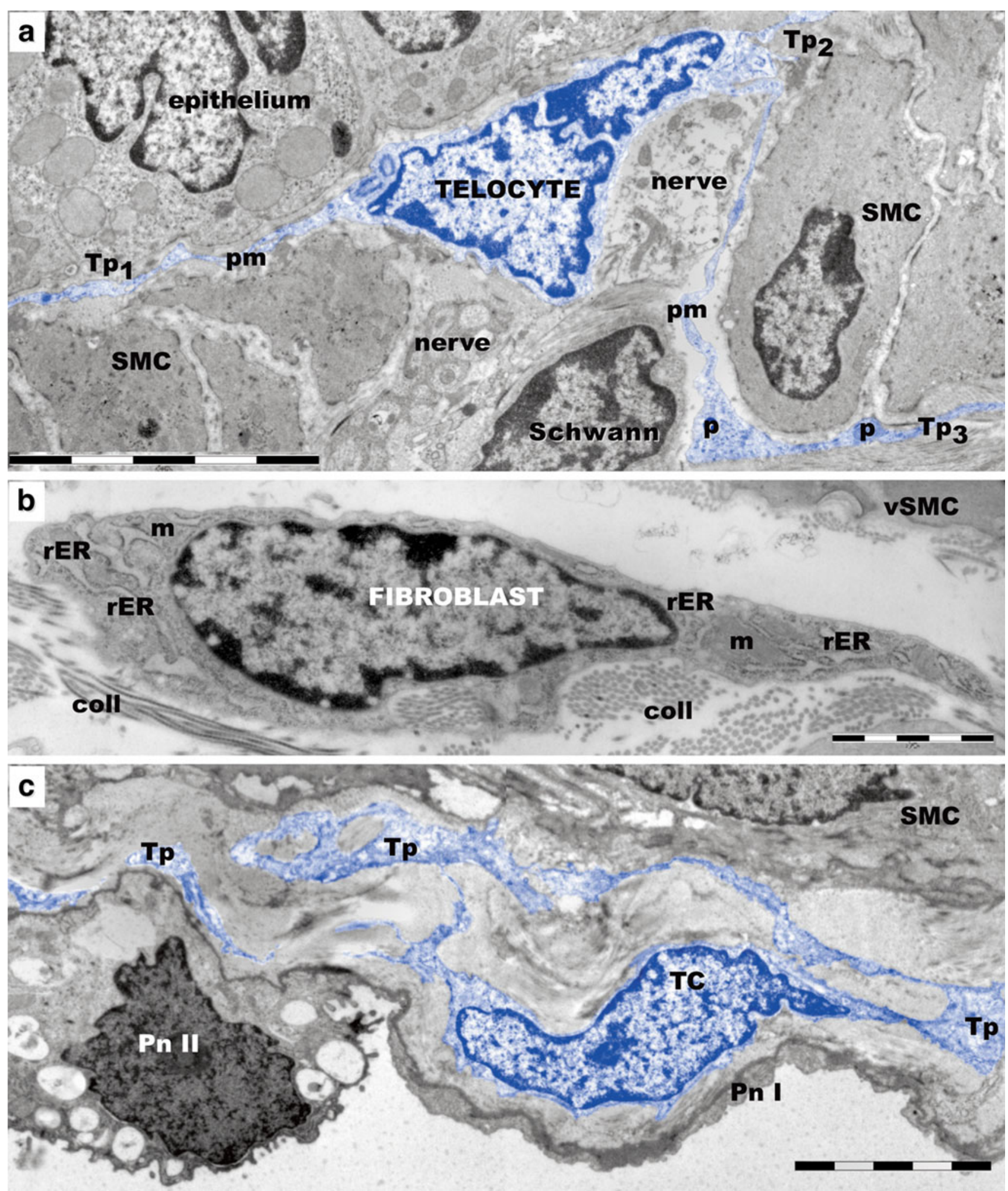

Fig. 1 Transmission electron microscopy: telocytes (TCs) in mouse terminal bronchioles (a, b) and human lung (c). a One telocyte (blue) extends two telopodes $(T p 1, T p 2)$ along the basement membrane of the bronchiolar epithelium. A third telopode (Tp3) is located among smooth muscle cells $(S M C)$. Schwann cells and nerve endings appear in close vicinity to the telocyte. Characteristic dilated podoms $(p)$ alternate with podomers $(\mathrm{pm})$, thin segments along the Tp. b A peri- bronchiolar fibroblast is shown for comparison with TCs: note the numerous dilated cisternae of rough endoplasmic reticulum $(r E R)$ and mitochondria $(m)$. The peri-bronchiolar interstitial space also has numerous collagen fibrils (coll) and vascular smooth muscle cells ( $v S M C)$. c TC and Tp border the epithelium at the level of the respiratory bronchiole. Pn I, type I pneumocyte; $P n$ II, type II pneumocyte. Scale bars $5 \mu \mathrm{m}(\mathbf{a}, \mathbf{c}), 2 \mu \mathrm{m}$ (b) 

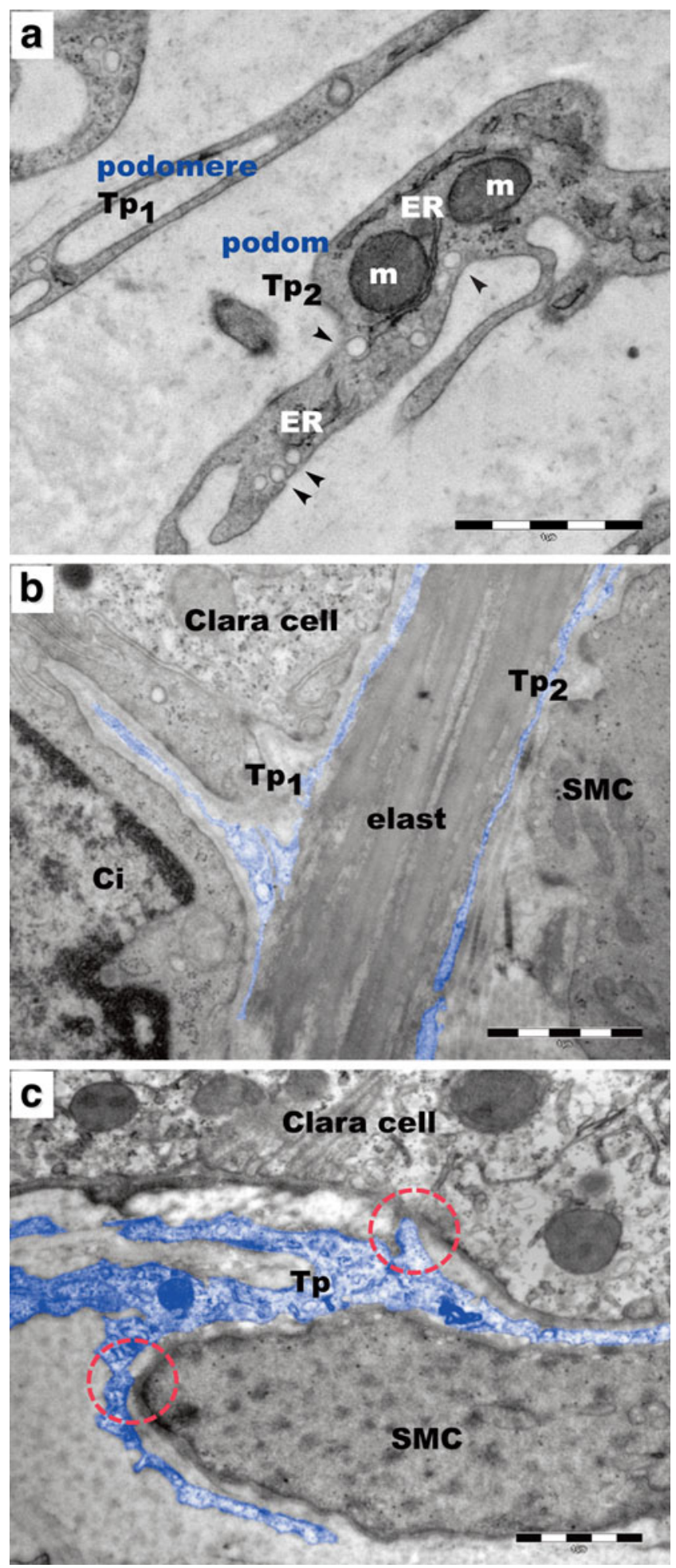

Immunofluorescence on paraffin-embedded sections

Adult mouse lungs were tested for vascular endothelial growth factor (VEGF) expression by immunohistochemistry using rabbit polyclonal VEGF (1:300; Abcam, Cambridge, UK) and by immunofluorescence using rat
Fig. 2 Transmission electron microscopy of telopodes (Tp) in the interstitium of mouse terminal bronchioles. a Note the characteristic thin podomeres (50-200 nm; below the resolving power of light microscope) (Tp1), as well as a specific podom (Tp2), a dilation containing mitochondria $(m)$, the endoplasmic reticulum $(E R)$ and caveolae (arrowheads). b Extremely thin telopodes (Tp1, Tp2; < $50 \mathrm{~nm}$ ) can be seen bordering elastin fibers (elast) on both sides, adjacent to the bronchiolar epithelium and smooth muscle cells $(S M C)$. $C i$, ciliated cell. c A telopode $(T p)$ has two contacts (encircled), one with the basement membrane of the epithelium and another with the basal lamina of a smooth muscle cell (SMC). Note the dichotomic pattern of Tp branching. Scale bars $1 \mu \mathrm{m}(\mathbf{a}-\mathbf{c})$

monoclonal Sca-1 (1:50; Abcam, Cambridge, UK). Immunolabeling was performed on 5 - $\mu$ m-thick sections from paraffin-embedded specimens fixed with $4 \%$ formalin. The samples were first deparaffinized in xylene, hydrated in alcohol series and washed in distilled water. After blocking endogenous peroxidase with $0.3 \% \mathrm{H}_{2} \mathrm{O}_{2}$, microwave heat-induced epitope-retrieval (in Tris/EDTA buffer, $\mathrm{pH}$ 9; DAKO, Carpinteria, CA, USA) was performed. Next, the slides were left to reach room temperature, washed in PBS and incubated with $2 \%$ BSA for $20 \mathrm{~min}$. Slides were incubated with primary antibody overnight at $4{ }^{\circ} \mathrm{C}$, followed by treatment with a standard labelled streptavidin-antibody biotin (LSAB) kit and development in 3,3'-diaminobenzidine chromogen substrate (DakoCytomation, Glostrup, Denmark) for immunohistochemistry. Slides were stained with donkey antirat antibody conjugated with AlexaFluor 488 (1:300, Invitrogen Molecular Probes, Eugene, OR, USA) for immunofluorescence.

For immunohistochemistry, the slides were counterstained with Mayer's haematoxylin; for immunofluorescence, the nuclei were stained with DAPI (Sigma Chemical, St. Louis, MO, USA). Images were captured on a Nikon Eclipse 600 microscope.

Negative controls were performed by omitting the primary antibody or by substituting the primary antibodies with nonimmune serum in an otherwise similar protocol.

\section{Results}

TCs (Figs. 1, 2, 3, 4, 5, 6, 7, 8) were present from the bronchi to the bronchoalveolar junction in both mouse (Fig. 1a) and human specimens (Fig. 1c). Although short segments of interstitial cells or cells with myocytic features (pericytes) have been observed previously by electron microscopy in the interalveolar septa, there was no clear ultrastructural proof for the presence of TCs. Fibroblasts (Fig. 1b), macrophages (Fig. 7), Schwann cells and nerve fibers (Fig. 1a) and mononuclear cells (Figs. 6,7) were also observed in the lung interstitium. 
Fig. 3 Connections between telocytes. a,b Telopodes (Tp1, $T p 2, T p 3)$ bordering the alveolar epithelium are connected by puncta adhaerentia junctions (white arrows). Dense structures (attachment plaques) connect $\mathrm{Tp}$ to the extracellular matrix (black arrows). Pn I, type I pneumocyte. c 60 -nm sections show Tp $(T p 1, T p 2)$ connected by manubria adhaerentia (dotted circles). d Exosomes containing shed vesicles $(s v)$ emerge from the Tp. One telopode (Tp1) enfolds a large vesicle $(l v)$ located in the extracellular space. Note the thickness of telopodes (Tp1, $T p 2$ ), which is comparable with the thickness of collagen fibrils (coll): approximately $50 \mathrm{~nm}$ (far below the resolving power of light microscope). Scale bars $1 \mu \mathrm{m}(\mathbf{a}-\mathbf{d})$
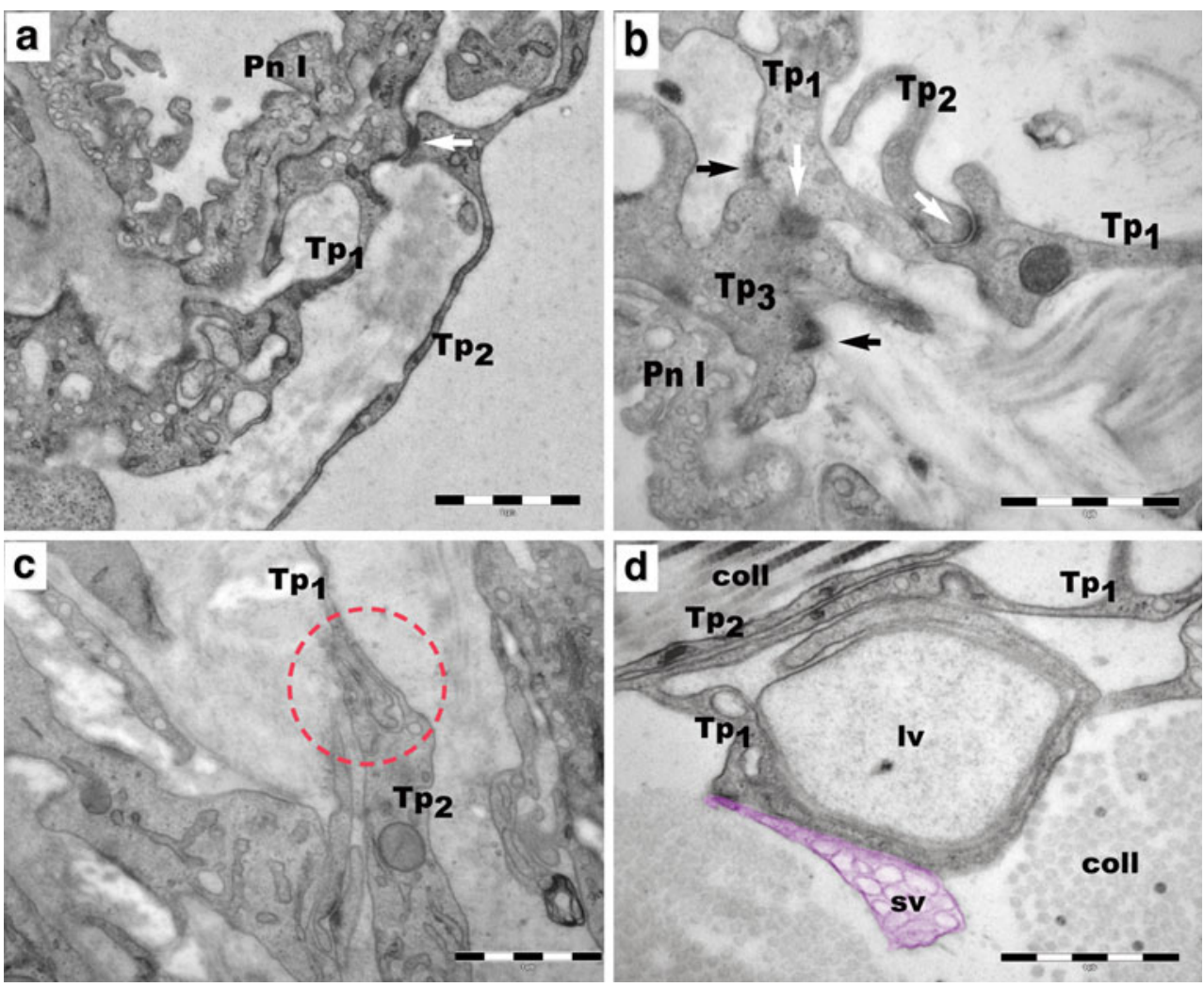

The shape of TCs was triangular (Fig. 1a), spindle (Fig. 1c), or stellate (Fig. 7), depending on the number of visible telopodes $(\mathrm{Tp})$. The $\mathrm{Tp}$ had a narrow emergence from the cellular body (Fig. 1a), were extremely long (30$90 \mu \mathrm{m}$ ) and sinuous (Fig. 6) and had a dichotomous pattern of branching (Fig. 2c). To evaluate the extension potential of the Tp, we assessed their actual length divided by the endto-end distance in a straight line and defined it as the convolution index (Hinescu et al. 2008, 2011); we calculated a mean convolution index of 3.5 . Tp had a moniliform aspect, as well as an uneven caliber (Fig. 1a, c) due to the irregular alternation of podomeres: thin $(45-100 \mathrm{~nm}) \mathrm{seg}-$ ments with podoms (150-300 nm) containing mitochondria, endoplasmic reticulum and caveolae (Fig. 2a). The podomeres were often extremely slender (Fig. 2b); their thickness was comparable with collagen fibrils (Fig. $3 \mathrm{~d}$ ).

TCs formed a labyrinthic system. The overlapping of Tp appears organized in a network alongside the airway tree and vascular system (Figs. 4a, 7a). TCs and Tp were present in the following locations:

- lining the basement membrane of the bronchiolar epithelium (Figs. 1a, 2b);

- in between clusters of airway smooth muscle cells of muscularis (Fig. 1a);

- in the periphery of airway smooth muscle cells (Fig. 1a);

- coating the respiratory epithelium at the bronchoalveolar junction (Fig. 6); and
- surrounding nerves (Fig. 1a), blood vessels (Fig. 6), or clusters of putative stem cells (Figs. 6a, 7a).

Confocal microscopy demonstrated positive reactions for two markers usually expressed by telocytes in other tissues: ckit and CD34 (Fig. 4). The positive cells were visibly located in the connective tissue of the peri-bronchiolar space, outside the smooth muscle layer. Most positive cells had a TC typical morphology, with long and slender cell projections (Tp) that follow a longitudinal course with respect to the long axis of the airways (Fig. 4a-d). Immunostaining for ckit and CD34 demonstrated the presence of double positive TCs with long prolongations in the interstitial space surrounding small bronchi and bronchioles (Fig. 4e-g). The primary expression of c-kit was on the cell body and in the proximal part of Tp (Fig. 4c, d, f); however, CD34 expression marked the $\mathrm{Tp}$, making them visible over a long distance (Fig. 4a, b, e). Putative SCs were detected based on Sca-1 expression (Fig. 5) in small clusters located in the peribronchiolar space, especially in between bronchioles and the accompanying blood vessels.

Electron microscopy demonstrated that TCs often extended their $\mathrm{Tp}$ around groups of mononuclear cells (Figs. 6a, 7a), with few ultrastructural features similar to stem cells (large nuclei, few endoplasmic reticulum cisternae, few mitochondria and ribosomes). The putative SCs were located in the same regions where Sca-1 positive cells have been detected by immunofluorescence. These 

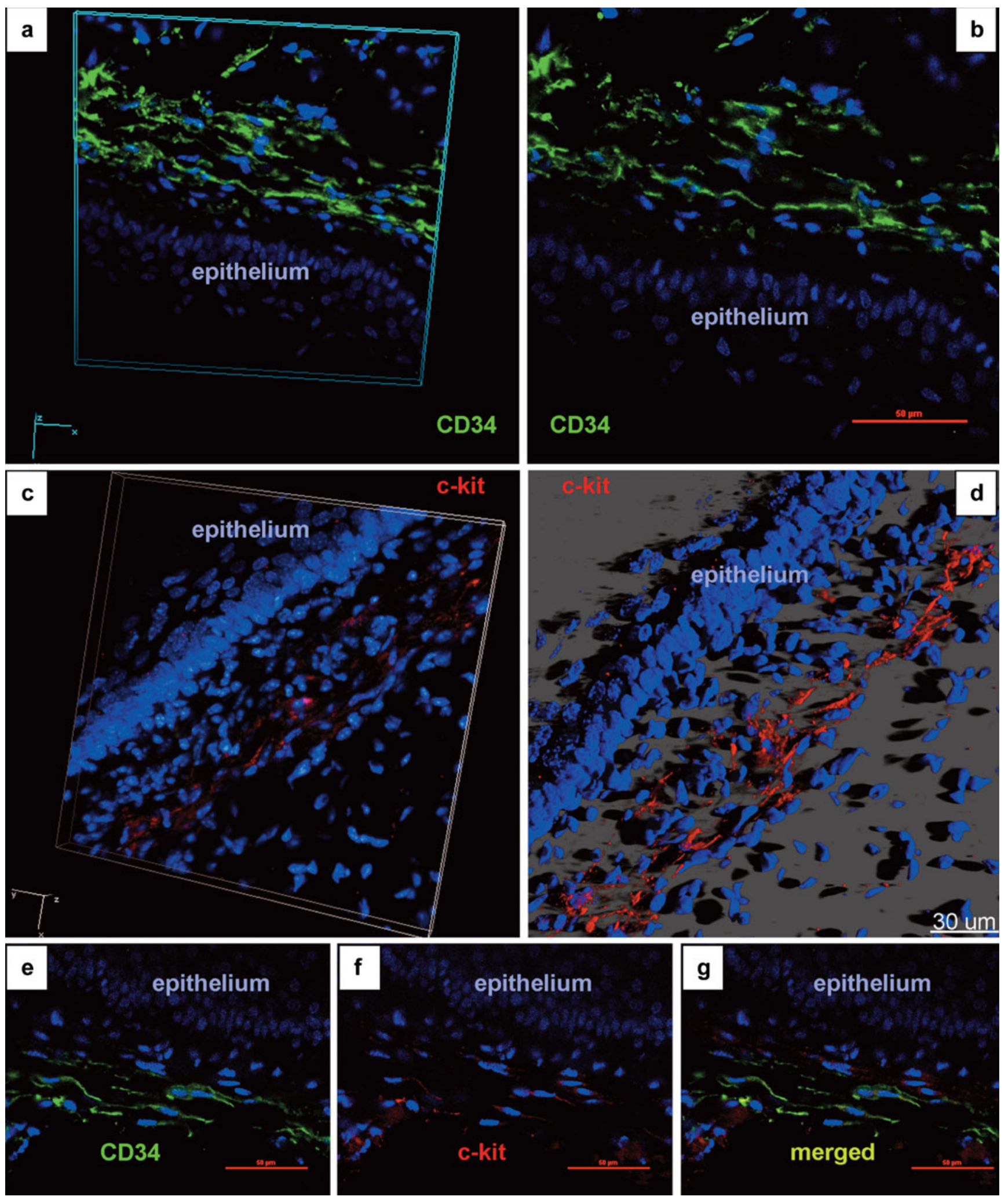

Fig. 4 Confocal microscopy of thick sections $(60 \mu \mathrm{m})$ of lung tissue from an adult mouse, with CD34 immunolabeling visible in the peribronchiolar space. a Volume reconstruction. b Confocal laser scanning microscopy. c c-kit immunolabeling, original volume reconstruction. d The same volume after deconvolution. Double immunofluorescence shows the labeling pattern for CD34 (e, green) and c-kit (f, red); the superimposed images are presented in $\mathbf{g}$. Nuclei were counterstained with DAPI. Confocal images were collected using the $60 \times 1.2$-NA water objective (z-axis step $0.16 \mu \mathrm{m}$ ) 
Fig. 5 Immunofluorescent labeling of Sca-1 positive cells (green) from the peribronchiolar space in the adult mouse lung, detected by confocal laser scanning microscopy. The nuclei were counterstained with DAPI (blue)

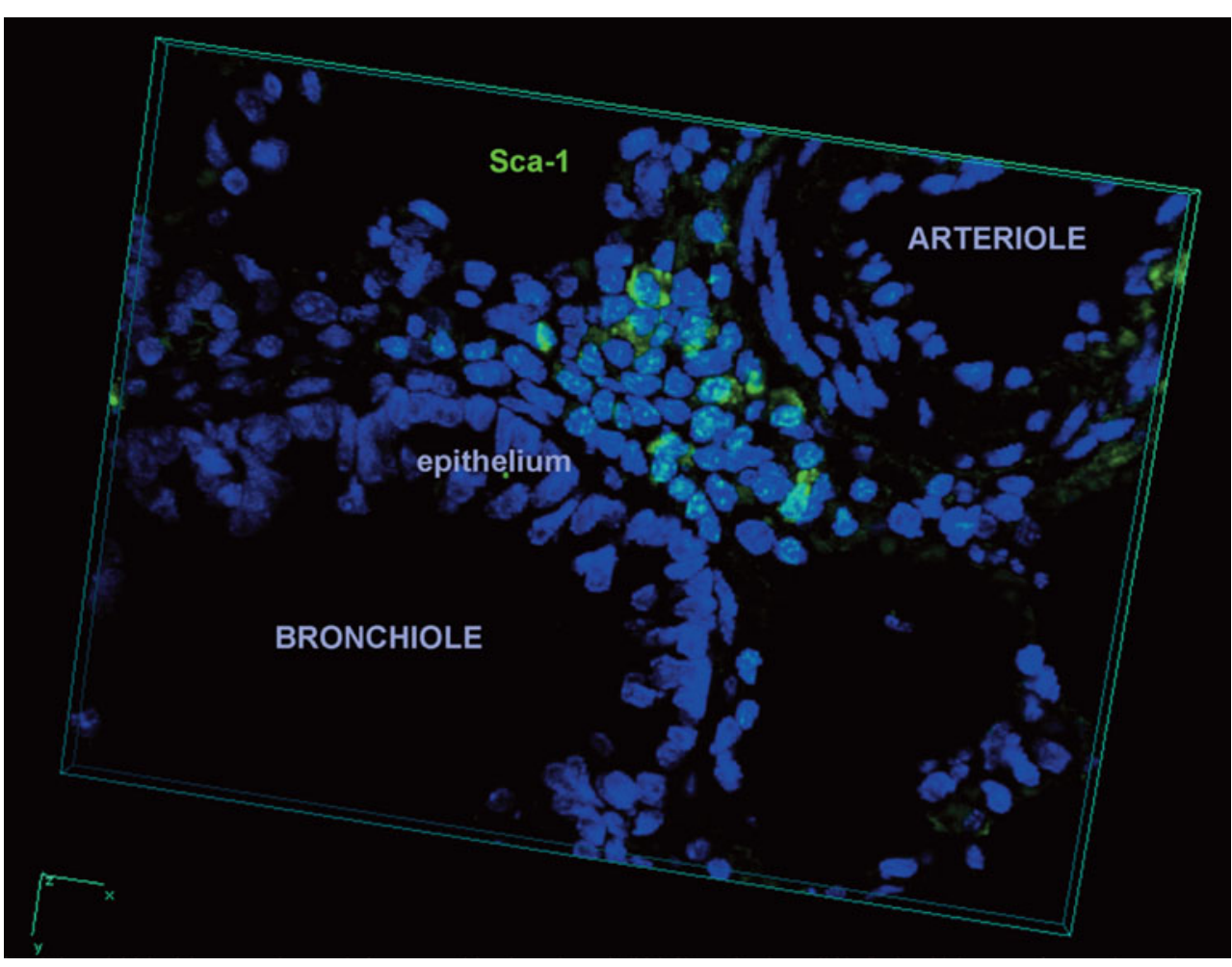

cells (either SCs or precursor cells) were clustered (two to five cells) in the interstitium of the bronchoalveolar junction, near blood vessels (Figs. 5, 6a).

Electron microscopy showed that $\mathrm{Tp}$ were coupled to each other by different types of junctions: puncta adhaerentia (Fig. 3a, b) manubria adhaerentia (Fig. 3c) and small electron-dense structures (Fig. 8). Tp also demonstrated close connections or junctions with the basement membrane of epithelial cells (Fig. 2c), basal lamina of airway smooth muscle cells (Fig. 2c), epithelial cells (Fig. 6b-d), macrophages (Fig. 7a, b), or putative stem cells (Fig. 6a, b). Shedding vesicles (100 nm vesicles) and exosomes (250$350 \mathrm{~nm}$ ) were frequently observed emerging from telopodes (Fig. 3d).

We also investigated the expression of molecules potentially involved in intercellular communication. Immunohistochemistry showed VEGF-positive TCs in the peri-bronchiolar space (Fig. 9). VEGF was expressed concomitantly at the level of the cell body and cell prolongations.

We also performed ET to detail heterocellular and homocellular communication. Tp were usually connected by puncta adhaerentia (Fig. 7c-f); however, there were also 10-nm, faintly electron-dense structures (Fig. 8). These small structures were generally clustered, indicating the presence of molecular junctions (Fig. 8c) between Tp and they were frequently seen connecting Tp and putative stem cells (Fig. 7d-g). ET also revealed that some segments of $\mathrm{Tp}$ (podomeres) are extremely narrow (approximately $100 \mathrm{~nm}$ diameter) and sometimes their thickness is comparable with collagen fibrils (Fig. 8c). Caveolae were observed in these narrow segments and had contacts with cellular membrane on the entire circumference of Tp (Fig. 8c, d).

\section{Discussion}

Traditionally, the recognition and characterization of cell types have been based on morphological characteristics that are visible using light and electron microscopy (Bell and Mooers 1997; Valentine 2002, 2003); however, topographical and functional criteria are also important. Five years ago, Vickaryous and Hall (2006) proposed an updated list of cell types for the adult Homo sapiens, with 411 cell types, including 145 types of neurons. However, most textbooks group different cells into a limited number of types. The modern, generalized scheme of tissue classification consists in four group subdivisions: epithelial, muscular, nervous and connective (interstitial) tissues. Additionally, a very small number of cell types could include epitheliocytes, mechanocytes (typical ex: fibroblasts), amoebocytes (wandering cells) and nerve cells (Willmer 1970).

During the last 5 years, we have collected and reported on numerous data showing the existence of a novel cell type that we have named telocytes (TCS); for reviews see (Popescu and Faussone-Pellegrini 2010; Popescu 2011b; Faussone-Pellegrini and Popescu 2011). This name was 
Fig. 6 Telocytes and a possible stem cell niche at the level of the bronchoalveolar junction (mouse). a A group of putative stem cells $(S C)$, underneath the alveolar epithelial cells $(P n I$, type I pneumocytes; $P n$ II, type II pneumocytes). The cluster of SCs (brown) is surrounded by telopodes (Tp1, Tp2; blue). TC, telocyte; $v S M C$, vascular smooth muscle cells. b Higher magnification of the upper boxed area shows one telopode (Tp1, blue) in contact with a type I pneumocyte (Pn I, black arrow) and a brown-colored $S C$ (white arrows). A shed vesicle visible in violet (asterisk). c Higher magnification of the lower boxed area in a shows a break in the basement membrane $(\mathrm{bm})$. A telopode (Tp2) makes contact (arrow) with a type I pneumocyte $(P n I)$. d TEM image shows a contact point (arrow) between a telopode $(T p 1)$ and a type I pneumocyte $(P n I)$. Scale bars $2 \mu \mathrm{m}(\mathbf{a}) ; 1 \mu \mathrm{m}(\mathbf{b}-\mathbf{d})$
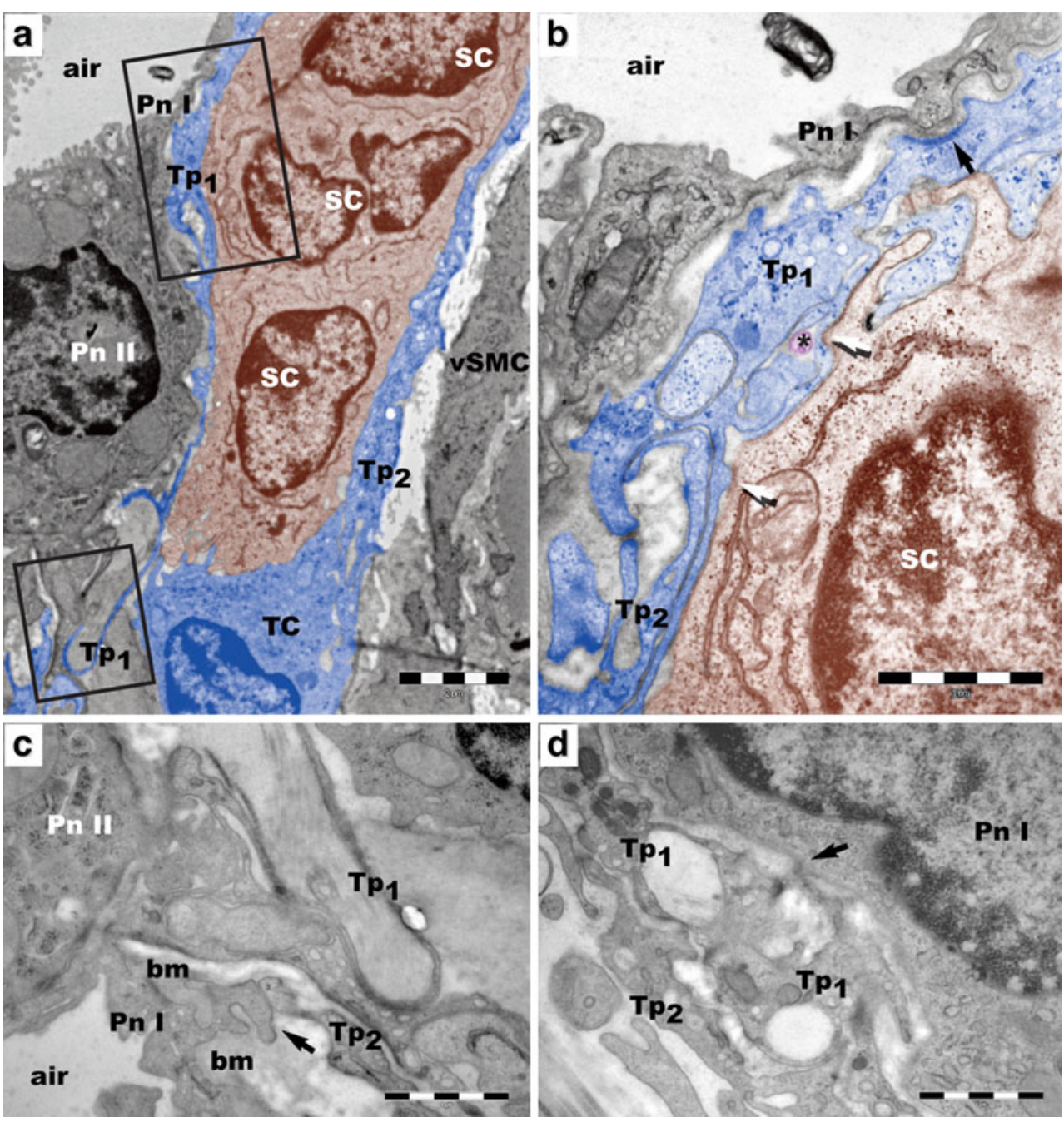

chosen to underscore the primary characteristic of TC cytoanatomy: telopodes, very long and extremely thin prolongations of the cell body. Formally, TCs belong to the connective tissue cell group, or may be considered mechanocytes. In any case, TCs are not epitheliocytes, muscle cells, or nerve cells, being located in the interstitial spaces. In brief, TCs are interstitial or stromal cells of mesenchymal origin. We have described TCs in many human and rodent organs:

a) cavitary: heart (Hinescu and Popescu 2005; Popescu et al. 2006a, 2009; Hinescu et al. 2006; Gherghiceanu and Popescu 2010, 2011; Kostin and Popescu 2009); pulmonary veins (Gherghiceanu et al. 2008); intestine (Popescu 2011a); gall bladder (Hinescu et al. 2007); and uterus and fallopian tube (Ciontea et al. 2005; Cretoiu et al. 2009; Popescu et al. 2005a, 2006b, 2007);

b) non-cavitary: pleura (Hinescu et al. 2011); skeletal muscle (Popescu et al. 2011b); mesentery (Hinescu et al. 2008); pancreas (Popescu et al. 2005b; Nicolescu et al. 2010); mammary gland (Gherghiceanu and Popescu 2005; Radu et al. 2005); and placenta (Suciu et al. 2007, 2010b).
Preliminary data about the presence of TC in trachea were recently reported (Zheng et al. 2011). Therefore, it seems reasonable to hypothesize that TCs exist in almost all organs. While no two TCs are identical in appearance, a generalized ultrastructural pattern or some guidelines can be established to identify TCs using electron microscopy. With regard to the immunophenotypes of TCs from various organs, TCs share some features rather than having overall similarity (Popescu and Faussone-Pellegrini 2010).

The data presented here may support the hypothesis of an integrative role for telocytes in lung physiology based on their involvement in mechanical support, intercellular signaling, immune surveillance and stem-cell guidance.

\section{Mechanical support and mechanotransduction}

We have previously suggested a mechanical supporting role for the 3D TC network existing in the mesentery (Hinescu et al. 2008). This paper describes a similar 3D network in the walls of the intralobular tree, which lacks cartilage. Therefore, we may hypothesize that the 3D network, at the 
Fig. 7 Transmission electron microscopy of mouse bronchoalveolar junction. a A telocyte (TC, blue) with numerous, abrupt emerging telopodes $(T p)$. Some Tp surround an array of putative stem cells $(S C) . v S M C$, vascular smooth muscle cells; Macro, macrophage. b Higher magnification of the black boxed area in a shows that a Tp passes between putative stem cells $(S C)$ and a macrophage (Macro).

Small dense structures (white arrows) connect the telopode (Tp1) with SCs, while the larger dense structures, puncta adhaerentia (black arrows), connect Tp with the macrophage. A small shed vesicle (violet, asterisk) is visible between the Tp and SC. c-g Electron tomography images of the red-boxed area in panel a. Digital sections from the grey area in panel $\mathbf{c}$ are enlarged in panel d. e, f Serial digital sections from lateral views of the tomographic volume at different levels. Images d-f show small bridging nanostructures (white arrows), which connect a Tp with an SC. A punctum adhaerens (black arrow) connects two $\mathrm{Tp}$ (Tp1, $T p 2) . d g$, dense granule. $\mathbf{g}$ Three-dimensional representation of connecting nanostructures (green dots) between $\mathrm{Tp}$ and $\mathrm{SC}$ in the vicinity of a dense granule (red) from telopode $T p 1$. Scale bars $5 \mu \mathrm{m}(\mathbf{a}) ; 1 \mu \mathrm{m}(\mathbf{b})$; $0.5 \mu \mathrm{m}(\mathbf{c}, \mathbf{d}) ; 0.2 \mu \mathrm{m}(\mathbf{e}-\mathbf{g})$
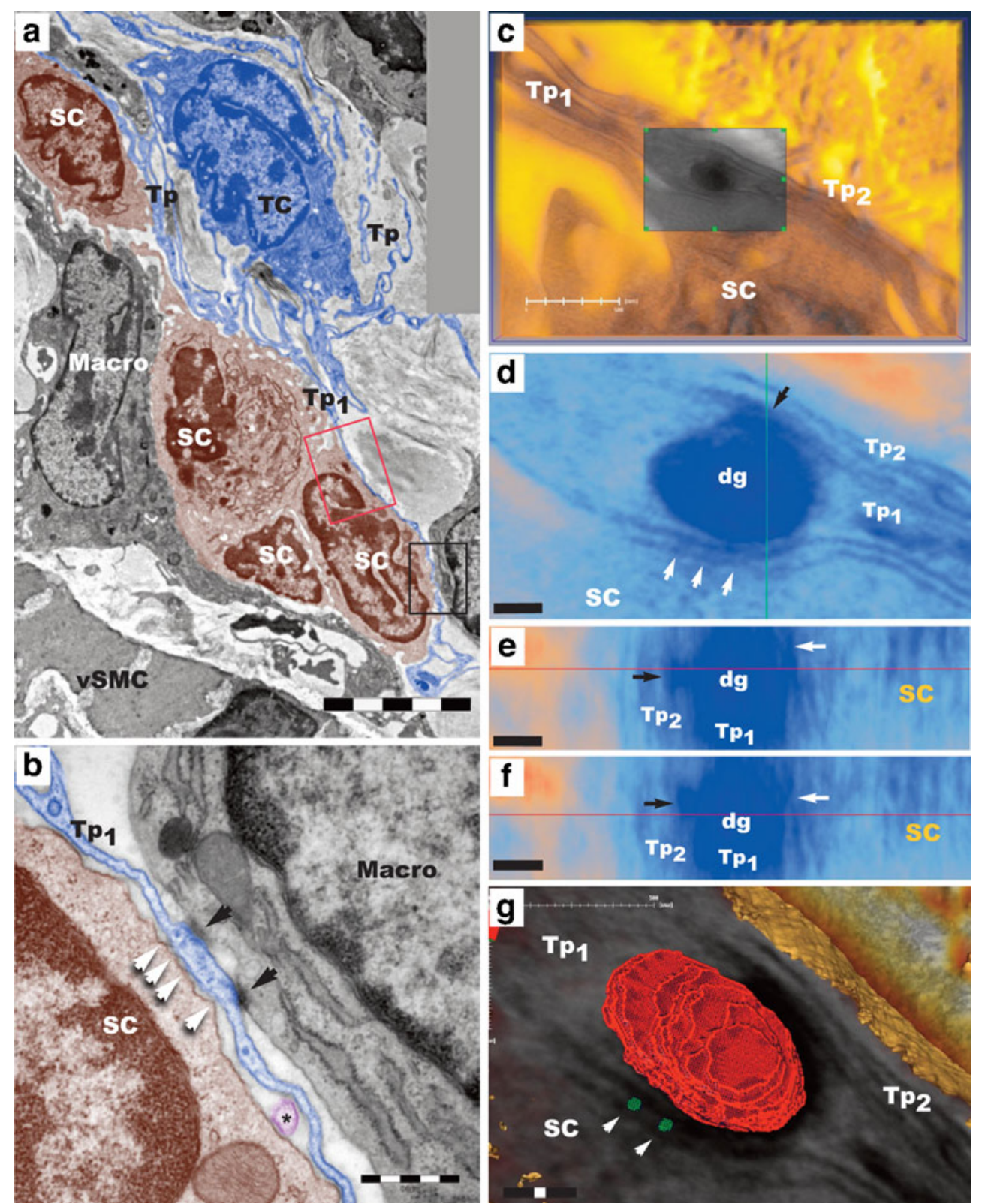

same time deformable and resistant, may contribute to keeping open the lumen of intralobular bronchioles and avoiding blood vessel closure during respiratory movements. TCs are frequently found in the vicinity of small blood vessels. Moreover, the convoluted conformation of $\mathrm{Tp}$ (convolution index 3.3) may be particularly important in tensional integration of the tissue (Ingberg 2006). Due to their distribution, TCs could be a key factor in lung tissue response to the mechanical stretch induced by the airflow and blood flow.

\section{Intercellular communication}

The results of this study demonstrate that TCs are connected in a network, which accompanies the respiratory tree. Notably, different types of pulmonary cells are interconnected through the 3D network of TCs. TCs seem to be involved in intercellular communication and longdistance signaling through:

- homocellular junctions between TCs (puncta adhaerentia and manubria adhaerentia) and

- heterocellular junctions (puncta adherentia, puncta adhaerentia minima): TC junctions with tissue-specific cells (e.g., epithelial cells), immunocompetent cells (e.g., macrophages) and putative SCs or progenitor cells.

Puncta adhaerentia and manubria adhaerentia have been described between mesenchymal cells and they seem to be involved in long-distance cellular communication (Wuchter et al. 2007; Franke 2009; Franke et al. 2009; Barth et al. 2009). 


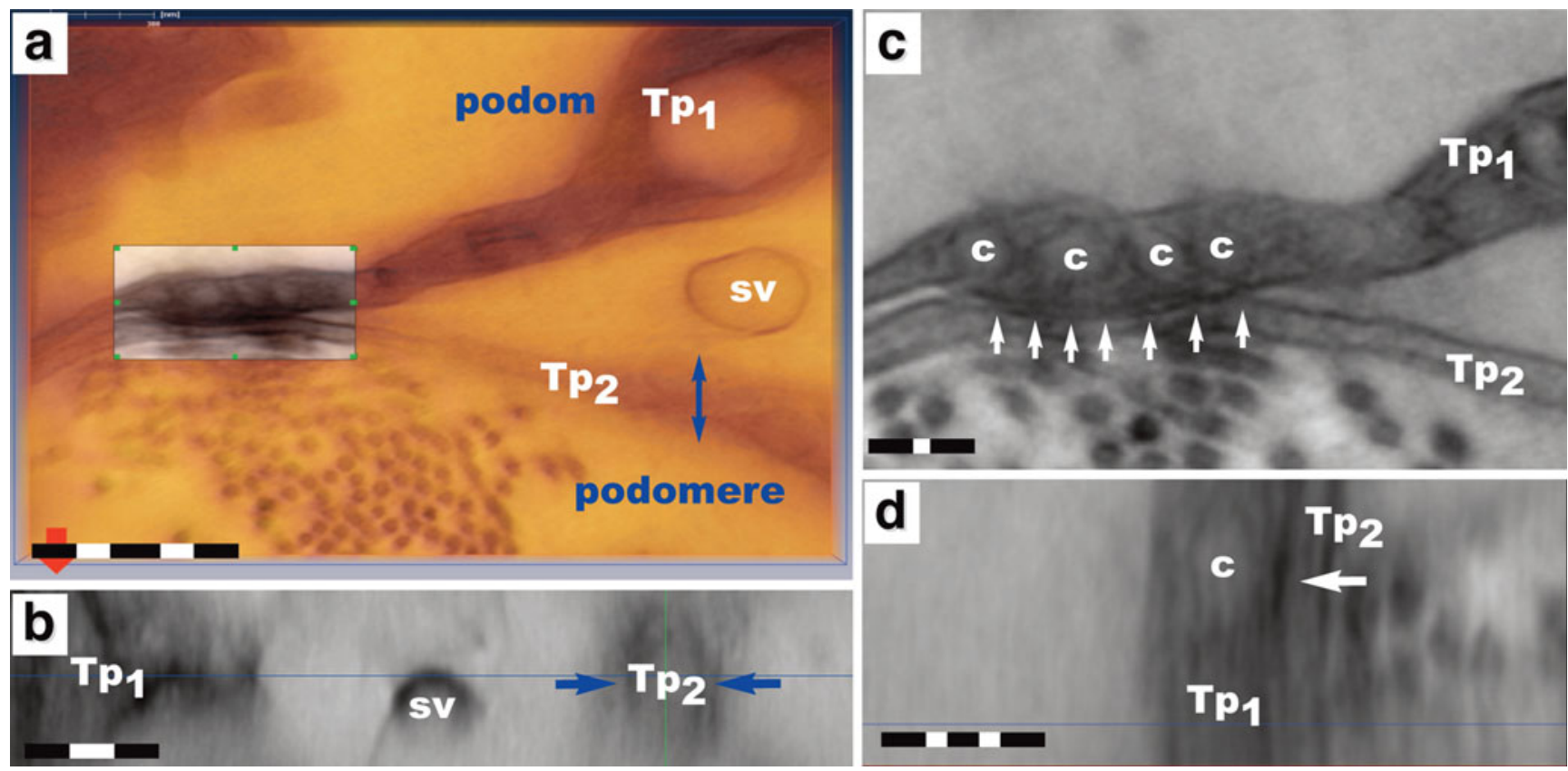

Fig. 8 a Electron tomography shows telopodes (Tp1, Tp2) with irregular contours. $s v$, shed vesicle. See also the 3D volume in Fig. S1. b A lateral view of the tomographic volume at the level of the doubleended arrow in a demonstrates that $\mathrm{Tp} 2$ is entirely embedded (arrows) in the thickness $(250 \mathrm{~nm})$ of the section. c Higher magnification of a digital section through the bright area in reveals that caveolae present

A different type of communication seems to occur via a sequence of $10 \mathrm{~nm}$ small foot-like nanostructures, suggesting molecular interactions (Fig. 8). This type of molecular connection has been observed previously between TCs and putative SCs or precursor cells (Fig. 7). Foot-like nanostructures have been described previously connecting intracellular organelles with important roles in calcium homeostasis (Popescu et al. 2006c; Gherghiceanu and Popescu 2007; Franzini-Armstrong 2007). The presence of caveolae as nodal signaling platforms (Bastiani and Parton 2010) in the segments connected by these 'molecular' junctions (Fig. 8) boosts the hypothesis that TCs are involved in local cellular homeostasis (Popescu and Faussone-Pellegrini 2010). in $T p 1$ establish contacts with the cellular membrane on the junctional side. Telopodes are connected by a cluster of contact points (arrows). $T p 2$ is extremely narrow $(<50 \mathrm{~nm})$ at the level of the junction. $c$, caveolae. d A lateral view of the tomographic volume at the level of one caveola (c) shows a $10-\mathrm{nm}$ contact point (arrow) between telopodes (Tp1,Tp2). Scale bars $0.5 \mu \mathrm{m}$ (a); $0.2 \mu \mathrm{m}(\mathbf{b}-\mathbf{d})$

TCs regularly generate exosomes and shed vesicles in the interstitial space (Figs. 3d, 8). These extracellular organelles seem to be involved in complex intercellular communication (Cocucci et al. 2009; Mathivanan et al. 2010) and exosomes are likely carriers of small RNAs, including regulatory microRNAs (Zomer et al. 2010; Cismasiu et al. 2011).

Immune surveillance

We have repeatedly reported the so-called 'stromal synapse' between TCs and immunoreactive cells (Popescu et al. 2005c; Suciu et al. 2010b; Hinescu et al. 2011). An immune surveillance role has been suggested for the fibroblast-like

Fig. 9 Immunohistochemical reaction for VEGF in the adult mouse lung. VEGF expression in telocytes (TCs) is more evident around bronchioles (a), as well as between a bronchiole and the accompanying vein (b). Tp extend in opposite directions and interconnect with similar neighboring cells. Nuclei were counterstained with hematoxylin. Scale bars $5 \mu \mathrm{m}$
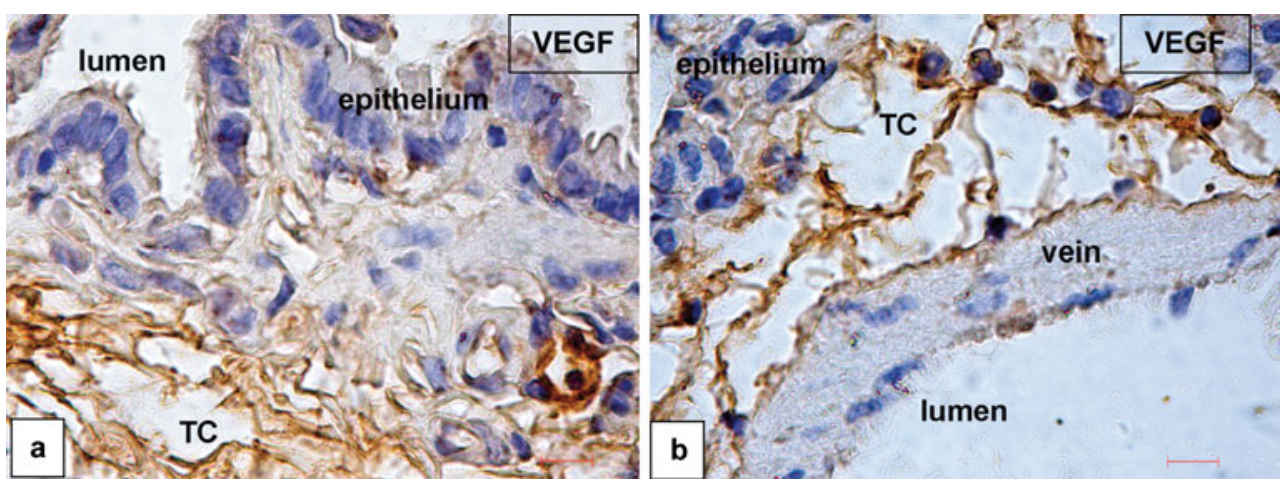
cells located in the human fallopian tubes, which have been termed a 'CD34-positive reticular network' (Yamazaki and Eyden 1996). Such direct contacts are also frequently formed in the lamina propria of the epithelium along the intralobular bronchiolar tree.

\section{The tandem telocytes-putative stem cells}

The respiratory tract seems to contain several sources of endogenous adult SCs (Murphy et al. 2008; Weiss et al. 2008; Stripp 2008; Bucchieri et al. 2009; Chistiakov 2010; Roomans 2010), which contribute to the repair of the airway wall. SCNs (Reynolds et al. 2000) and specialized neuroepithelial bodies serving as reservoirs of progenitors (Engelhardt 2001) have been described; although these SCs are dispensable for lung homeostasis, they are required for lung injury repair (Giangreco et al. 2009). SCs require a niche - a basic unit of tissue physiology, integrating signals that mediate the balanced response of SCs to the needs of the tissue (Scadden 2006; Walker et al. 2009). Cells in developing tissues are also influenced by multiple signals through direct cell-to-cell contacts (Doljanski 2004; Roy et al. 2011).

This study reveals a direct connection between TCs and putative SCs, suggesting that TCs are stromal support cells within the lung SCN. The identification of a TC-SC tandem (due to specific intercellular junctions) provides a new perspective linking a potential cell source located in subepithelial niches of the bronchiolar tree with the hypothetical cell-guiding capacity of TCs (Popescu et al. 2011a).

\begin{abstract}
Acknowledgements The authors thank Professor S. Kostin for his valuable help in processing Fig. 4D. This work was supported by the National Authority for Scientific Research project number PN 09.33/ $2009(02.04,02.14)$ and by the Sectorial Operational Programme Human Resources Development (SOP HRD), financed from the European Social Fund and by the Romanian Government under contract number POSDRU/89/1.5/S/64109. Financial support from the Cord Blood Center (Cluj Napoca) is greatfully acknowledged.
\end{abstract}

Open Access This article is distributed under the terms of the Creative Commons Attribution Noncommercial License, which permits any noncommercial use, distribution and reproduction in any medium, provided the original author(s) and source are credited.

\section{References}

Bani D, Formigli L, Gherghiceanu M, Faussone-Pellegrini MS (2010) Telocytes as supporting cells for myocardial tissue organization in developing and adult heart. J Cell Mol Med 14:2531-2538

Barth M, Schumacher H, Kuhn C, Akhyari P, Lichtenberg A, Franke WW (2009) Cordial connections: molecular ensembles and structures of adhering junctions connecting interstitial cells of cardiac valves in situ and in cell culture. Cell Tissue Res 337:63-77
Bastiani M, Parton RG (2010) Caveolae at a glance. J Cell Sci 123:3831-3836

Bell G, Mooers AO (1997) Size and complexity among multicellular organisms. Biol J Linn Soc Lond 60:345-363

Bojin FM, Gavriliuc OI, Cristea MI, Tanasie G, Tatu CS, Panaitescu C, Paunescu V (2011) Telocytes within human skeletal muscle stem cell niche. J Cell Mol Med. doi:10.1111/j.15824934.2011.01386.x

Bucchieri F, Fucarino A, Rizzuto L, Pitruzzella A, Noto A, Cappello F, Zummo G (2009) Stem Cell Populations and Regenerative Potential in Chronic Inflammatory Lung Diseases. Open Tissue Eng Regen Med J 2:34-39

Cantarero CI, Luesma BMJ, Junquera EC (2011a) Identification of telocytes in the lamina propria of rat duodenum: transmission electron microscopy. J Cell Mol Med 15:26-30

Cantarero I, Luesma MJ, Junquera C (2011b) The primary cilium of telocytes in the vasculature: electron microscope imaging. J Cell Mol Med. doi:10.1111/j.1582-4934.2011.01312.x

Chistiakov DA (2010) Endogenous and exogenous stem cells: a role in lung repair and use in airway tissue engineering and transplantation. J Biomed Sci 17:92

Ciontea SM, Radu E, Regalia T, Ceafalan L, Cretoiu D, Gherghiceanu M, Braga RI, Malincenco M, Zagrean L, Hinescu ME, Popescu LM (2005) C-kit immunopositive interstitial cells (Cajal-type) in human myometrium. J Cell Mol Med 9:407-420

Cismasiu V, Radu E, Popescu LM (2011) miR-193 expression differentiates telocytes from other stromal cells. J Cell Mol Med 15:1071-1074

Cocucci E, Racchetti G, Meldolesi J (2009) Shedding microvesicles: artefacts no more. Trends Cell Biol 19:43-51

Cozzi E, Ackerman KG, Lundequist A, Drazen JM, Boyce JA, Beier DR (2011) The naive airway hyperresponsiveness of the A/J mouse is Kit-mediated. Proc Natl Acad Sci USA 108:12787-12792

Cretoiu SM, Cretoiu D, Suciu L, Popescu LM (2009) Interstitial Cajallike cells of human Fallopian tube express estrogen and progesterone receptors. J Mol Histol 40:387-394

Doljanski F (2004) The sculpturing role of fibroblast-like cells in morphogenesis. Perspect Biol Med 47:339-356

Engelhardt JF (2001) Stem cell niches in the mouse airway. Am J Respir Cell Mol Biol 24:649-652

Eyden B, Curry A, Wang G (2011) Stromal cells in the human gut show ultrastructural features of fibroblasts and smooth muscle cells but not myofibroblasts. J Cell Mol Med 15:1483-1491

Faussone-Pellegrini MS, Bani D (2010) Relationships between telocytes and cardiomyocytes during pre- and post-natal life. J Cell Mol Med 14:1061-1063

Faussone-Pellegrini MS, Popescu LM (2011) Telocytes. BioMol Concepts (in press)

Franke WW (2009) Discovering the molecular components of intercellular junctions - a historical view. Cold Spring Harb Perspect Biol 1:a003061

Franke WW, Rickelt S, Barth M, Pieperhoff S (2009) The junctions that don't fit the scheme: special symmetrical cell-cell junctions of their own kind. Cell Tissue Res 338:1-17

Franzini-Armstrong C (2007) ER-mitochondria communication. How privileged? Physiology (Bethesda) 22:261-268

Gard JJ, Asirvatham SJ (2011) The "slow pathway" potential: fact or fiction? Circ Arrhythm Electrophysiol 4:125-127

Gevaert T, De Vos R, Everaerts W, Libbrecht L, Van Der Aa F, van den Oord J, Roskams T, De Ridder D (2011) Characterization of upper lamina propria interstitial cells in bladders from patients with neurogenic detrusor overactivity and bladder pain syndrome. J Cell Mol Med. doi:10.1111/j.1582-4934.2011.01262.x

Gherghiceanu M, Popescu LM (2005) Interstitial Cajal-like cells (ICLC) in human resting mammary gland stroma. Transmission electron microscope (TEM) identification. J Cell Mol Med 9:893-910 
Gherghiceanu M, Popescu LM (2007) Electron microscope tomography: further demonstration of nanocontacts between caveolae and smooth muscle sarcoplasmic reticulum. J Cell Mol Med 11:1416-1418

Gherghiceanu M, Popescu LM (2009) Human epicardium: ultrastructural ancestry of mesothelium and mesenchymal cells. J Cell Mol Med 13:2949-2951

Gherghiceanu M, Popescu LM (2010) Cardiomyocyte precursors and telocytes in epicardial stem cell niche: electron microscope images. J Cell Mol Med 14:871-877

Gherghiceanu M, Popescu LM (2011) Heterocellular communication in the heart. Electron tomography of telocyte-myocyte junctions. J Cell Mol Med 15:1005-1011

Gherghiceanu M, Hinescu ME, Andrei F, Mandache E, Macarie CE, Faussone-Pellegrini MS, Popescu LM (2008) Interstitial Cajallike cells (ICLC) in myocardial sleeves of human pulmonary veins. J Cell Mol Med 12:1777-1781

Gherghiceanu M, Manole CG, Popescu LM (2010) Telocytes in endocardium: electron microscope evidence. J Cell Mol Med $14: 2330-2334$

Giangreco A, Arwert EN, Rosewell IR, Snyder J, Watt FM, Stripp BR (2009) Stem cells are dispensable for lung homeostasis but restore airways after injury. Proc Natl Acad Sci USA 106 (23):9286-9291

Gittenberger-de Groot AC, Winter EM, Poelmann RE (2010) Epicardium-derived cells (EPDCs) in development, cardiac disease and repair of ischemia. J Cell Mol Med 14:1056-1060

Hinescu ME, Popescu LM (2005) Interstitial Cajal-like cells (ICLC) in human atrial myocardium. J Cell Mol Med 9:972-975

Hinescu ME, Gherghiceanu M, Mandache E, Ciontea SM, Popescu LM (2006) Interstitial Cajal-like cells (ICLC) in atrial myocardium: ultrastructural and immunohistochemical characterization. J Cell Mol Med 10:243-257

Hinescu ME, Ardeleanu C, Gherghiceanu M, Popescu LM (2007) Interstitial Cajal-like cells in human gallbladder. J Mol Histol 38:275-284

Hinescu ME, Popescu LM, Gherghiceanu M, Faussone-Pellegrini MS (2008) Interstitial Cajal-like cells in rat mesentery: an ultrastructural and immunohistochemical approach. J Cell Mol Med $12: 260-270$

Hinescu ME, Gherghiceanu M, Suciu L, Popescu LM (2011) Telocytes in pleura: two- and three-dimensional imaging by transmission electron microscopy. Cell Tissue Res 343:389-397

Hsia CC, Hyde DM, Ochs M, Weibel ER, ATS/ERS Joint Task Force on Quantitative Assessment of Lung Structure (2010) An official research policy statement of the American Thoracic Society/ European Respiratory Society: standards for quantitative assessment of lung structure. Am J Respir Crit Care Med 181:394-418

Ingberg DE (2006) Cellular mechanotransduction: putting all the pieces together again. FASEB J 20:811-827

Jiang JX, Li L (2009) Potential therapeutic application of adult stem cells in acute respiratory distress syndrome. Chin J Traumatol $12: 228-233$

Kim CF (2007) Paving the road for lung stem cell biology: bronchioalveolar stem cells and other putative distal lung stem cells. Am J Physiol Lung Cell Mol Physiol 293:L1092-L1098

Kim CF, Jackson EL, Woolfenden AE, Lawrence S, Babar I, Vogel S, Crowley D, Bronson RT, Jacks T (2005) Identification of bronchioalveolar stem cells in normal lung and lung cancer. Cell 121:823-835

Klumpp D, Horch RE, Kneser U, Beier JP (2010) Engineering skeletal muscle tissue - new perspectives in vitro and in vivo. J Cell Mol Med 14:2622-2629

Kostin S (2010) Myocardial telocytes: a specific new cellular entity. J Cell Mol Med 14:1917-1921

Kostin S (2011) Types of cardiomyocyte death and clinical outcomes in patients with heart failure. J Am Coll Cardiol 57:1532-1534
Kostin S, Popescu LM (2009) A distinct type of cell in myocardium: interstitial Cajal-like cells (ICLCs). J Cell Mol Med 13:295-308

Kotton DN, Fine A (2008) Lung stem cells. Cell Tissue Res 331:145156

Li TS, Cheng K, Lee ST, Matsushita S, Davis D, Malliaras K, Zhang Y, Matsushita N, Smith RR, Marbán E (2010) Cardiospheres recapitulate a niche-like microenvironment rich in stemness and cell-matrix interactions, rationalizing their enhanced functional potency for myocardial repair. Stem Cells 28:2088-2098

Limana F, Capogrossi MC, Germani A (2011) The epicardium in cardiac repair: from the stem cell view. Pharmacol Ther 129:82-96

Liu X, Engelhardt JF (2008) The glandular stem/progenitor cell niche in airway development and repair. Proc Am Thorac Soc 5:682-688

Mandache E, Gherghiceanu M, Macarie C, Kostin S, Popescu LM (2010) Telocytes in human isolated atrial amyloidosis: ultrastructural remodelling. J Cell Mol Med 14:2739-2747

Mathivanan S, Ji H, Simpson RJ (2010) Exosomes: Extracellular organelles important in intercellular communication. J Proteomics 73:1907-1920

Matthay MA, Goolaerts A, Howard JP, Lee JW (2010) Mesenchymal stem cells for acute lung injury: preclinical evidence. Crit Care Med 38:S569-S573

Murphy J, Summer R, Fine A (2008) Stem cells in airway smooth muscle: state of the art. Proc Am Thorac Soc 5:11-14

Nicolescu MI, Manole CG, Gherghiceanu M, Hinescu ME, Popescu LM (2010) Telocytes - players of the pancreatic stromal puzzle. Eur J Cancer Suppl 5:51

Polykandriotis E, Popescu LM, Horch RE (2010) Regenerative medicine: then and now - an update of recent history into future possibilities. J Cell Mol Med 14:2350-2358

Popescu LM (2011a) Telocytes - a novel type of interstitial cells. In: Braisant O, Wakamatsu H, Kang I, Allegaert K, Lenbury Y, Wacholtz A (eds) Recent researches in modern medicine HISTEM'11. WSEAS Press, Cambridge, pp 424-432

Popescu LM (2011b) Telocytes and stem cells: a tandem in cardiac regenerative medicine. Curr Med Chem 18:94

Popescu LM, Faussone-Pellegrini MS (2010) Telocytes - a case of serendipity: the winding way from interstitial cells of Cajal (ICC), via interstitial Cajal-like cells (ICLC) to telocytes. J Cell Mol Med 14:729-740

Popescu LM, Ciontea SM, Cretoiu D, Hinescu ME, Radu E, Ionescu N, Ceausu M, Gherghiceanu M, Braga RI, Vasilescu F, Zagrean L, Ardeleanu C (2005a) Novel type of interstitial cell (Cajal-like) in human fallopian tube. J Cell Mol Med 9:479-523

Popescu LM, Hinescu ME, Ionescu N, Ciontea SM, Cretoiu D, Ardelean C (2005b) Interstitial cells of Cajal in pancreas. J Cell Mol Med 9:169-190

Popescu LM, Gherghiceanu M, Cretoiu D, Radu E (2005c) The connective connection: interstitial cells of Cajal (ICC) and ICClike cells establish synapses with immunoreactive cells. Electron microscope study in situ. J Cell Mol Med 9:714-730

Popescu LM, Gherghiceanu M, Hinescu ME, Cretoiu D, Ceafalan L, Regalia T, Popescu AC, Ardeleanu C, Mandache E (2006a) Insights into the interstitium of ventricular myocardium: interstitial Cajal-like cells (ICLC). J Cell Mol Med 10:429-458

Popescu LM, Vidulescu C, Curici A, Caravia L, Simionescu AA, Ciontea SM, Simion S (2006b) Imatinib inhibits spontaneous rhythmic contractions of human uterus and intestine. Eur $\mathrm{J}$ Pharmacol 546:177-181

Popescu LM, Gherghiceanu M, Mandache E, Cretoiu D (2006c) Caveolae in smooth muscles: nanocontacts. J Cell Mol Med 10:960-990

Popescu LM, Ciontea SM, Cretoiu D (2007) Interstitial Cajal-like cells in human uterus and fallopian tube. Ann N YAcad Sci 1101:139-165

Popescu LM, Gherghiceanu M, Manole CG, Faussone-Pellegrini MS (2009) Cardiac renewing: interstitial Cajal-like cells nurse 
cardiomyocyte progenitors in epicardial stem cell niches. J Cell Mol Med 13:866-886

Popescu LM, Manole CG, Gherghiceanu M, Ardelean A, Nicolescu MI, Hinescu ME, Kostin S (2010) Telocytes in human epicardium. J Cell Mol Med 14:2085-2093

Popescu LM, Gherghiceanu M, Kostin S, Faussone-Pellegrini MS (2011a) Telocytes and heart renewing. In: Wang P, Kuo $\mathrm{CH}$, Takeda N, Singal PK (eds) Adaptation biology and medicine, vol 6. Cell adaptations and challenges. Narosa, New Delhi, pp 17-39

Popescu LM, Manole E, Serboiu CS, Manole CG, Suciu LC, Gherghiceanu M, Popescu BO (2011b) Identification of telocytes in skeletal muscle interstitium: implication for muscle regeneration. J Cell Mol Med 15:1379-1392

Radenkovic G (2011) Two patterns of development of interstitial cells of Cajal in the human duodenum. J Cell Mol Med. doi:10.1111/ j.1582-4934.2011.01287.x

Radu E, Regalia T, Ceafalan L, Andrei F, Cretoiu D, Popescu LM (2005) Cajal-type cells from human mammary gland stroma: phenotype characteristics in cell culture. J Cell Mol Med 9:748-752

Raiser DM, Kim CF (2009) Commentary: Sca-1 and cells of the lung: A matter of different sorts. Stem Cells 27:606-611

Reynolds SD, Giangreco A, Power JH, Stripp BR (2000) Neuroepithelial bodies of pulmonary airways serve as a reservoir of progenitor cells capable of epithelial regeneration. Am J Pathol 156:269-278

Roomans GM (2010) Tissue engineering and the use of stem/ progenitor cells for airway epithelium repair. European Cells and Materials (ECM) 19:284-299

Roy S, Hsiung F, Kornberg TB (2011) Specificity of Drosophila cytonemes for distinct signaling pathways. Science 332:354-358

Rupp H, Rupp TP, Alter P, Jung N, Pankuweit S, Maisch B (2010) Intrapericardial procedures for cardiac regeneration by stem cells: need for minimal invasive access (AttachLifter) to the normal pericardial cavity. Herz 35:458-465

Russell JL, Goetsch SC, Gaiano NR, Hill JA, Olson EN, Schneider JW (2011) A dynamic notch injury response activates epicardium and contributes to fibrosis repair. Circ Res 108:51-59

Rusu MC, Pop F, Hostiuc S, Curcă GC, Streinu-Cercel A (2011a) Extrahepatic and intrahepatic human portal interstitial cajal cells. Anat Rec (Hoboken) 294:1382-1392

Rusu MC, Pop F, Hostiuc S, Dermengiu D, Lală AI, Ion DA, Mănoiu VS, Mirancea N (2011b) The human trigeminal ganglion: c-kit positive neurons and interstitial cells. Ann Anat. doi:10.1016/j. aanat.2011.06.005

Sassoli C, Pini A, Mazzanti B, Quercioli F, Nistri S, Saccardi R, Orlandini SZ, Bani D, Formigli L (2011) Mesenchymal stromal cells affect cardiomyocyte growth through juxtacrine Notch-1/ Jagged-1 signaling and paracrine mechanisms: Clues for cardiac regeneration. J Mol Cell Cardiol 51:399-408

Scadden DT (2006) The stem-cell niche as an entity of action. Nature 441:1075-1079

Schraufnagel DE (1990) Electron microscopy of the lung. Marcel Dekker, CRC Press, New York

Stripp BR (2008) Hierarchical organization of lung progenitor cells: is there an adult lung tissue stem cell? Proc Am Thorac Soc 5:695-698

Suciu L, Popescu LM, Gherghiceanu M (2007) Human placenta: de visu demonstration of interstitial Cajal-like cells. J Cell Mol Med 11:590-597
Suciu L, Popescu LM, Regalia T, Ardelean A, Manole CG (2009) Epicardium: interstitial Cajal-like cells (ICLC) highlighted by immunofluorescence. J Cell Mol Med 13:771-777

Suciu L, Nicolescu MI, Popescu LM (2010a) Cardiac telocytes: serial dynamic images in cell culture. J Cell Mol Med 14:2687-2692

Suciu L, Popescu LM, Gherghiceanu M, Regalia T, Nicolescu MI, Hinescu ME, Faussone-Pellegrini MS (2010b) Telocytes in human term placenta: morphology and phenotype. Cells Tissues Organs 192:325-339

Susman S, Soritau O, Rus-Ciuca D, Tomuleasa C, Pop VI, Mihu CM (2010) Placental stem cell differentiation into islets of Langerhanslike glucagon-secreting cells. Rom J Morphol Embryol 51:733-738

Tommila M (2010) Granulation tissue formation. The effect of hydroxyapatite coating of cellulose on cellular differentiation. $\mathrm{PhD}$ Thesis, University of Turku, Finland

Valentine JW (2002) Cell-type number and complexity. In: Pagel M (ed) Encyclopedia of evolution, Volume 1. Oxford University Press, New York, pp 144-146

Valentine JW (2003) Cell types, numbers and body plan complexity. In: Hall BK, Olson WM (eds) Keywords and concepts in evolutionary developmental biology. Harvard University Press, Cambridge, pp 35-53

Vickaryous MK, Hall BK (2006) Human cell type diversity evolution, development and classification with special reference to cells derived from the neural crest. Biol Rev Cambridge 81:425-455

Walker MR, Patel KK, Stappenbeck TS (2009) The stem cell niche. J Pathol 217:169-180

Warburton D, Perin L, Defilippo R, Bellusci S, Shi W, Driscoll B (2008) Stem/progenitor cells in lung development, injury repair, and regeneration. Proc Am Thorac Soc 5:703-706

Weiss DJ, Kolls JK, Ortiz LA, Panoskaltsis-Mortari A, Prockop DJ (2008) Stem cells and cell therapies in lung biology and lung diseases. Proc Am Thorac Soc 15:637-667

Willmer EN (1970) Cytology and evolution, 2nd edn. Academic Press, New York

Wuchter P, Boda-Heggemann J, Straub BK, Grund C, Kuhn C, Krause U, Seckinger A, Peitsch WK, Spring H, Ho AD, Franke WW (2007) Processus and recessus adhaerentes: giant adherens cell junction systems connect and attract human mesenchymal stem cells. Cell Tissue Res 328:499-514

Xiao J, Liang D, Chen YH (2011) The genetics of atrial fibrillation: from the bench to the bedside. Annu Rev Genomics Hum Genet. doi:10.1146/annurev-genom-082410-101515

Yamazaki K, Eyden BP (1996) Ultrastructural and immunohistochemical studies of stromal cells in lamina propria of human fallopian tube ampullar mucosa: the recognition of 'CD34 positive reticular network' and its putative function for immune surveillance. J Submicrosc Cytol Pathol 28:325-337

Zheng Y, Li H, Manole CG, Sun A, Ge J, Wang X (2011) Telocytes in trachea and lungs. J Cell Mol Med. doi:10.1111/j.15824934.2011.01404.X

Zhou J, Zhang Y, Wen X, Cao J, Li D, Lin Q, Wang H, Liu Z, Duan C, Wu K, Wang C (2010) Telocytes accompanying cardiomyocyte in primary culture: two- and three-dimensional culture environment. J Cell Mol Med 14:2641-2645

Zomer A, Vendrig T, Hopmans ES, van Eijndhoven M, Middeldorp JM, Pegtel DM (2010) Exosomes: fit to deliver small RNA. Commun Integr Biol 3:447-450 